\title{
Self-concept dialectical transformation: A study in a women's prison
}

\author{
A dialética de transformação do autoconceito: \\ um estudo no cárcere feminino
}

\author{
Lysia Rachel Moreira BASÍLIO' \\ Antonio ROAZZI ${ }^{2}$ \\ Alexsandro Medeiros do NASCIMENTO ${ }^{3}$ \\ José Arturo Costa ESCOBAR ${ }^{4}$
}

\begin{abstract}
The present study investigated incarceration as a possible triggering factor of self-concept transformations. Self-concept consists of a set of multiple dimensions organized hierarchically functioning as cognitive schemas. It is a structural complex product of reflective activity, and it is susceptible to changes as the individual encounters new situations, life transitions, and social roles. To investigate the transformations in the self-concept structure, 150 incarcerated women responded to the Feminine Inventory of the Self-Concept's Gender Schemas, Self-Concept Clarity Scale and Situational Self-Awareness Scale. The results showed dynamic and multidimensional organization of self-concept in the women investigated, including various categories of the self. The elements analyzed indicate that prison, an undesirable life event in adulthood, is a driver of transformations in the dynamics of self-concept.
\end{abstract}

Keywords: Prisons; Self; Self-concept; Self-perception; Women.

\section{Resumo}

O presente trabalho elegeu o encarceramento como possível fator desencadeador de transformações no autoconceito. Este é composto por múltiplas dimensões do self organizadas hierarquicamente e funciona como esquemas da cognição. É ainda um produto estrutural complexo da atividade reflexiva, permeável a mudanças promovidas por novas situações,

1 Centro Universitário do Vale do Ipojuca, Faculdade de Psicologia, Departamento de Psicologia. Av. Adjair da Silva Casé, 800, Indianópolis, 55024-740, Caruaru, PE, Brasil. Correspondência para/Correspondence to: L.R.M. BASÍLIO. E-mail: <lysia.psi@gmail.com>.

2 Universidade Federal de Pernambuco, Departamento de Psicologia, Núcleo de Pesquisa em Epistemologia Experimental e Cultural. Recife, PE, Brasil.

${ }^{3}$ Universidade Federal de Pernambuco, Departamento de Psicologia, Programa de Pós-Graduação em Psicologia Cognitiva. Recife, PE, Brasil.

${ }^{4}$ Universidade Federal de Pernambuco, Centro de Ciências Sociais Aplicadas, Grupo de Estudos em Álcool e outras Drogas. Recife, PE, Brasil.

Article based on doctoral disertation of L.R.M. BASÍLIO, entitled "A dialética de transformação do self e do autoconceito: dimensões autorrefletidas no cárcere feminino". Universidade Federal de Pernambuco, 2013.

Acknowledged: The authors are grateful for the financial support provided by Conselho Nacional de Desenvolvimento Científico e Tecnológico. 
transições e papéis sociais. Para investigar as transformações e estrutura do autoconceito, 150 mulheres encarceradas responderam ao protocolo contendo o Inventário Feminino dos Esquemas de Gênero do Autoconceito, a Escala de Clareza do Autoconceito e a Escala de Autoconsciência Situacional. Os achados demonstraram organização dinâmica e multidimensional do autoconceito das mulheres, onde foram encontradas categorias diversas do self. Os elementos analisados configuram o cárcere como evento da vida adulta impulsionador de transformações na dinâmica do funcionamento do autoconceito.

Palavras-chave: Prisões; Self; Autoconceito; Autopercepção; Mulheres.

Self-concept can be defined as a product of human reflective activity and consists of a set of multiple dimensions organized hierarchically that can play a more or less central role at different times in life, functioning as cognitive schemas. Among a multitude of important roles of self-schemas in the self is the characteristic of being a perceptual reality filter, which includes self-perception and perception of others in different social situations (L'Écuyer, 1978, 1985).

Self-concept is also defined as a structural complex product of reflective activity, and it is susceptible to changes as the individual encounters new situations, life transitions, and social roles, i.e., it is simultaneously stable and dynamic (Caur \& Riar, 2013; Dasgupta, 2013; Demo, 1992; B. Hammer, Hammer, \& Butler, 2014; Knutzen \& Kennedy, 2012), and environmental stability is a key factor in the stable facet of the self.

This instability and the possibility of changes in self-concept in adulthood are assumptions that have not been widely discussed in the literature, although some studies have considered this possibility. Mortimer, Finch, and Kumka (1981), for example, consider the hybrid character of this construct: there would be a certain stability required for its role in self-referencing in individuals, mixed with self-concept instability, responsible for the changes. According to Rocha (2007), self-concept instabilities lead to self-concept changes in old age, which occur due to the losses inherent in the aging process and the need to adjust to new life circumstances.

Similarly, George (2000) refers to the protective nature of self-concept in older age since it may be positively changed in this stage of life as the possibility of dealing with unavoidable losses. influenced, mainly by the loss of social roles and the existence of negative age stereotypes (George, 2000; Mortimer et al., 1981; Rocha, 2007).

Cole et al. (2001) consider that although the stability of individual differences in self-concept dimensions tend to increase with age, there is a general self-concept principle that it is developed and stabilized according to the different periods of development. However, this organizing and transforming principle can be interrupted by abrupt developmental, social, and educational transitions that individuals may go through at any time in life.

In Brazil, studies that deserve mentioning are those carried out by Tamayo (Giavoni \& Tamayo, 2000, 2005; Tamayo, 1981), who also defends an organizing principle of self-concept. This author defines self-concept as hierarchically and multidimensionally organized self-perceptions. Self-concept contents are all elements of selfperception, and self-concept dimensions are the categories of the self that are organized consistently and dynamically since they can change due to social situations and relationships.

This study examines the hypothesis of self-concept transformation throughout life. Incarceration or imprisonment, an undesirable and stigmatized life event, would be able to cause transformations in the dynamic and malleable properties of self-concept. Such transformations were investigated, especially considering the length of incarceration of the participants.

Demo (1992) emphasizes that, traditionally, most researchers view self-concept as structural elements of the self that are relatively stable and characteristic of an individual. Very few have focused on temporal aspects of self-concept and therefore little is known about the social conditions that may be responsible for changes and new 
stability in self-concept, as well as its dynamic, changing, emerging qualities.

Since environmental instability is one of the consequences of incarceration, or deprivation of liberty by serving a sentence due to criminal offense, it may contribute to self-concept transformations in those who serve sentences. Although the methodological difficulties in understanding the transformations in self-concept in incarcerated people disconnecting these transformations from those that occurred before incarceration, the access to manifestations of self-concept can be understood, through the self-referencing in the scales used, as explanatory of the self-concept dynamics. Based on the participants' self-referencing, the self-concept susceptibility to changes due to environmental factors encountered throughout life can be inferred.

\section{Method}

The study sample consisted of 150 women (Mean age 29.05, SD 9.7). At the time the study was carried out, the participants were serving a sentence (prison) or were awaiting trial (jail), in the State of Pernambuco, Brazil, in closed prison conditions in both cases. Their average number of arrests was 1.58 (SD 3.10), and their average length of incarceration was 20.40 months (SD 19.11). They were serving sentences for drug trafficking, and they all probably had, at least, primary or secondary education (46.8\% elementary and middle school and $46.1 \%$ high school), according to their ability to read and understand the questions and items of the instruments administered.

\section{Instruments and Procedures}

Data were collected using the following instruments, a socio-demographic questionnaire and three different scales. All items were answered on a 1 to 5-point Likert scales, ranging from 1 (very little identification with the item to be answered), and 5 (strong identification with the item to be answered). The instruments are described below.

Inventário Feminino dos Esquemas de Gênero do Autoconceito (IFEGA, Feminine Inventory of the Self-Concept's Gender Schemas) (Giavoni \& Tamayo, 2005): composed of seventy-five items that assess the masculine and feminine schemas of women self-concept, the level of development of these schemas, and their perceptual patterns.

Self-Concept Clarity Scale (Campbell et al., 1996), Portuguese version by Nascimento (2008): composed of twelve items that assess the structural, unidimensional, and epistemological aspects of selfconcept and its clarity, internal consistency, and stability. Self-concept clarity can be defined as the extent to which the contents of an individual's perceived personal attributes are clearly defined, internally consistent, and stable.

Escala de Autoconsciência Situacional (Situational Self-Awareness Scale) (Nascimento, 2008): composed of thirteen items that measure individual differences in cognitive ability to self-focus (situational) with emphasis on non-anxious forms of self-awareness (reflection) and anxious forms of self-awareness (rumination) and on cognitive mediation of self-awareness through mental imagery (iconic mediation). Some examples of typical scale items are: "Right now, I am examining an aspect that concerns me" (Item 1, Reflection), "Right now, I am fantasizing about a situation in which there is something that concerns me" (Item 05, Rumination), and "Right now, I see myself in my mind" (Item 10, Iconic Mediation).

The present study was approved by the Ethics Committee for research on humans of the Universidade Federal de Pernambuco, (Federal University of Pernanbuco) (Process $n^{\circ}$ 438/2011). Through a member of staff at the prisons, an invitation was initially made to some women (in their own cell) to participate in this study. The invitation was later reinforced by the researcher in a private interview room, when the research objectives were explained and the participants were assured of the confidentiality of their individual responses. After the participants signed two copies of the consent form, the instruments were administered, and they were informed they were free to withdraw at any time. 


\section{Results}

The reliability of the IFEGA was measured, and it showed adequate Cronbach's alpha values (above 0.70 ), which indicates high reliability. Some internal consistency coefficients found in the present study were higher than those reported in the study that introduced this instrument (Giavoni \& Tamayo, 2005).

The correlation matrix of the Self-Concept Clarity Scale and the Situational Self-Awareness Scale with all variables (items), confirmed the adequacy of these instruments to factor analysis by the Kaiser-Meyer-Olkin (KMO) and Bartlett's test of sphericity (Hair Junior, Anderson, Tatham, \& Black, 2005; Reis, 2001). Through semantic analysis, five items were eliminated from the original SelfConcept Clarity Scale to obtain an adequate instrument with a KMO value of 0.892 .

In the Situational Self-Awareness Scale, KMO value was 0.719 . Through semantic analysis, four items were eliminated from the original scale due to factor inconsistency, resulting in a 2-factor structure: Factor 1-Reflection, since it demonstrated a non-anxious or neutral attention paid to the self, making it was possible to suppose the pursuit of self-knowledge or epistemic interest of the self; and Factor 2 - Rumination. In this case, the semantic analysis showed a more anxious self-focus, referring to negative content of the self and a more ruminative and negatively stereotyped activity.

\section{Correlation and regression analysis}

Spearman correlation was used to evaluate the relationship between the following independent variables, Age, Length of Incarceration in months, Incarcerated Siblings, Incarcerated Parents, Number of Arrests, and Level of Education, and the factors of the Situational Self-Awareness Scale (Rumination and Reflection), Self-Concept Clarity Scale, and the Feminine Inventory of the Self-Concept's Gender Schemas (Boldness, Egocentrism, Negligence, Sensuality, Inferiority, and Social Adjustment).

Table 1 shows all correlation coefficients and levels of significance found. The Spearman's rank correlation coefficients (rho) ranged from 0.176 to
-0.481 . Several significant correlations were found, but although significant, most of them were considered weak (rho $<0.3$ ); nevertheless, these correlations are interesting in terms of the objectives of this study. However, 10 moderate correlations $(0.301<r h o<0.7)$ were found; all of them were highly significant $(p<0.01)$.

The analyses showed that only some of the independent variables adequately explained the variation in the dependent variable values (scale factors), as can be seen in Table 2 .

With regard to the IFEGA, multiple regression showed that $3.4 \%$ of the variation in the factor Boldness is explained by Level of Education; 2.9\% of the variation in the factor egocentrism is explained by Age; $6.2 \%$ and $10.5 \%$ of the variation in the factor Sensuality is explained by these two variables, respectively; and finally, $5.8 \%$ and $8.8 \%$ of the variation of the factor Inferiority is also is explained by Age and Level of Education, respectively.

As for the Situational Self-Awareness Scale, $4.0 \%$ and $7.3 \%$ of the variation in the factor Rumination is explained by Age and Level of Education, respectively, and $3.5 \%$ of the variation in the factor Reflection is explained by Length of Incarceration. In the Self-Concept Clarity Scale, the only variable with explanatory power was Length of Incarceration (5.4\%).

Correlation analysis was carried out to investigate the relationship between the Dependent and Independent Variables of the Multiple Regression. Pearson's correlation coefficient $(r)$, which shows the likelihood of such a relationship occurring by sampling error (assuming the null hypothesis to be true), was calculated. In addition, the magnitude of the correlation coefficient $(r)$ indicates the strength of the association between variables (Dancey \& Reidy, 2006). There were 19 statistically significant correlations, which are shown in bold in Table 3.

Pearson's correlation coefficients ranged from $r=0.232, p<0.01$ (Self-Concept Clarity, Age) to $r=-0.250, p<0.01$ (Sensuality, Age). In the IFEGA factors, there were positive correlations between Boldness and the variables Length of Incarceration and Level of Education (stronger 
Table 1

Spearman's rank correlation coefficients between the independent variables and the factors

\begin{tabular}{|c|c|c|c|c|c|c|c|c|c|c|c|c|c|c|c|}
\hline & & a & $\mathrm{b}$ & c & $d$ & $\mathrm{e}$ & $f$ & $\mathrm{~g}$ & $h$ & $\mathrm{i}$ & j & k & 1 & $m$ & $n$ \\
\hline \multirow[t]{2}{*}{$a$} & rho & 1 & & & & & & & & & & & & & \\
\hline & $p$ & & & & & & & & & & & & & & \\
\hline \multirow{2}{*}{ b } & rho & $0.246^{* *}$ & 1 & & & & & & & & & & & & \\
\hline & $p$ & 0.002 & & & & & & & & & & & & & \\
\hline \multirow[b]{2}{*}{ C } & rho & -0.059 & 0.052 & 1 & & & & & & & & & & & \\
\hline & $p$ & 0.481 & 0.538 & & & & & & & & & & & & \\
\hline \multirow{2}{*}{$d$} & rho & -0.119 & 0.054 & $0.290^{*}$ & 1 & & & & & & & & & & \\
\hline & $p$ & 0.147 & 0.515 & 0.000 & & & & & & & & & & & \\
\hline \multirow{2}{*}{ e } & rho & 0.124 & $0.304^{* *}$ & 0.133 & $0.188^{*}$ & 1 & & & & & & & & & \\
\hline & $p$ & 0.130 & 0.000 & 0.111 & 0.021 & . & & & & & & & & & \\
\hline \multirow{2}{*}{ f } & rho & 0.101 & $0.318^{* *}$ & -0.152 & 0.045 & 0.043 & 1 & & & & & & & & \\
\hline & $p$ & 0.233 & 0.000 & 0.076 & 0.597 & 0.615 & & & & & & & & & \\
\hline \multirow[b]{2}{*}{ g } & rho & -0.027 & -0.097 & 0.023 & 0.028 & -0.124 & -0.099 & 1 & & & & & & & \\
\hline & $p$ & 0.740 & 0.241 & 0.784 & 0.736 & 0.132 & 0.247 & . & & & & & & & \\
\hline \multirow{2}{*}{ h } & rho & 0.052 & $0.248^{* *}$ & 0.147 & $0.179^{*}$ & $0.192^{*}$ & -0.035 & $0.260^{* *}$ & 1 & & & & & & \\
\hline & $p$ & 0.532 & 0.002 & 0.079 & 0.029 & 0.019 & 0.683 & 0.001 & . & & & & & & \\
\hline \multirow{2}{*}{ i } & rho & $0.242^{* *}$ & -0.021 & -0.023 & $-0.218^{*}$ & -0.081 & -0.069 & -0.151 & -0.085 & 1 & & & & & \\
\hline & $p$ & 0.003 & 0.798 & 0.786 & 0.011 & 0.327 & 0.419 & 0.067 & 0.301 & & & & & & \\
\hline \multirow[b]{2}{*}{ j } & rho & 0.121 & $0.253^{* *}$ & -0.061 & 0.119 & 0.076 & $0.221^{* *}$ & 0.001 & $0.318^{* *}$ & 0.101 & 1 & & & & \\
\hline & $p$ & 0.142 & 0.002 & 0.463 & 0.147 & 0.353 & 0.008 & 0.994 & 0.000 & 0.218 & . & & & & \\
\hline \multirow{2}{*}{ k } & rho & $-0.186^{*}$ & 0.015 & -0.007 & 0.070 & 0.109 & 0.031 & 0.090 & 0.130 & $-0.392^{* *}$ & 0.106 & 1 & & & \\
\hline & $p$ & 0.022 & 0.855 & 0.933 & 0.394 & 0.185 & 0.715 & 0.275 & 0.115 & 0.000 & 0.197 & . & & & \\
\hline \multirow{2}{*}{ । } & rho & -0.088 & 0.005 & -0.042 & 0.058 & 0.015 & 0.014 & -0.051 & -0.099 & $-0.205^{*}$ & -0.152 & $0.214^{* *}$ & 1 & & \\
\hline & $p$ & 0.282 & 0.950 & 0.619 & 0.482 & 0.851 & 0.867 & 0.540 & 0.230 & 0.012 & 0.064 & 0.009 & & & \\
\hline \multirow{2}{*}{$\mathrm{m}$} & rho & $-0.210^{\star *}$ & -0.148 & 0.069 & 0.115 & 0.083 & $-0.235^{* *}$ & 0.130 & $0.310^{* *}$ & -0.018 & $0.293^{* *}$ & $0.209^{*}$ & $0.215^{* *}$ & 1 & \\
\hline & $p$ & 0.010 & 0.071 & 0.412 & 0.160 & 0.312 & 0.005 & 0.115 & 0.000 & 0.832 & 0.000 & 0.010 & 0.008 & . & \\
\hline \multirow{2}{*}{$n$} & rho & $-0.213^{* *}$ & -0.108 & 0.049 & 0.116 & -0.022 & -0.138 & $0.263^{* *}$ & 0.035 & $-0.481^{* *}$ & $-0.212^{* *}$ & $0.397^{* *}$ & $0.322^{* *}$ & 0.059 & 1 \\
\hline & $p$ & 0.009 & 0.189 & 0.558 & 0.159 & 0.787 & 0.102 & 0.001 & 0.674 & 0.000 & 0.009 & 0.000 & 0.000 & 0.476 & . \\
\hline \multirow[t]{2}{*}{0} & rho & 0.080 & -0.036 & 0.022 & -0.014 & 0.028 & -0.154 & $0.176^{*}$ & $0.316^{* *}$ & $0.190^{*}$ & $0.314^{* *}$ & $-0.173^{*}$ & $-0.168^{*}$ & $0.291^{* *}$ & -0.117 \\
\hline & $p$ & 0.333 & 0.659 & 0.793 & 0.865 & 0.735 & 0.068 & 0.032 & 0.000 & 0.020 & 0.000 & 0.035 & 0.039 & 0.000 & 0.154 \\
\hline
\end{tabular}

Note: "Significant correlation, $p<0.05$. ${ }^{* *}$ Significant correlation, $p<0.01$ (Marked in bold).

IFEGA: Feminine Inventory of the Self-Concept's Gender Schemas (Inventário Feminino dos Esquemas de Gênero do Autoconceito); a: Age; b: Length of incarceration (months); c: Incarcerated siblings; d: Incarcerated parents; e: Number of arrests; f: Level of education; g: Rumination (Situational Self-Awareness); h: Reflection (Situational Self-Awareness); i: Self-Concept Clarity; j: IFEGA Boldness; k: IFEGA Egocentrism; I: IFEGA Negligence; m: IFEGA Sensuality; n: IFEGA Inferiority; O: IFEGA Social Adjustment.

correlation) and negative correlations between: Egocentrism and the variables Age and Age When Committed the Crime; Sensuality and the variables Age When Committed the Crime, Length of Incarceration, Age, and Level of Education (the last two were more significant); Inferiority and the variables Level of Education, Age When Committed the Crime, Incarcerated Siblings, Length of Incarceration, and Age (the last one was stronger); and finally, Social Adjustment and the variable Level of Education.
In the factors of the Situational SelfAwareness Scale, a negative correlation was found between Rumination and Number of Arrests (stronger) and a positive correlation between this factor and Incarcerated Siblings. There was a positive correlation between the factor Reflection and Length of Incarceration. The single Self-Concept Clarity Scale factor was found to be positively correlated with Age and Age When Committed the Crime (strong correlations in both cases). 
Table 2

Stepwise multiple regression between each one of the factors of the scales used (dependent variables) and age, incarcerated siblings, incarcerated parents, number of arrests, length of incarceration, and level of education (independent variables)

\begin{tabular}{|c|c|c|c|c|c|c|c|c|c|}
\hline Model & $r$ Pearson & $R$ & $R^{2}$ & $R^{2}$ Adjusted & Standard Error of the Estimate & $R^{2}$ Change & F Change & $g|1 / g| 2$ & $p$ \\
\hline \multicolumn{10}{|l|}{ Boldness } \\
\hline Level of education & 0.184 & 0.184 & 0.034 & 0.027 & 9.86 & 0.034 & 5.182 & $1 / 148$ & 0.024 \\
\hline \multicolumn{10}{|l|}{ Egocentrism } \\
\hline Age & 0.169 & 0.170 & 0.029 & 0.022 & 9.88 & 0.029 & 4.387 & $1 / 148$ & 0.038 \\
\hline Negligence & \multicolumn{9}{|c|}{ No variable was included the equation } \\
\hline \multicolumn{10}{|l|}{ Sensuality } \\
\hline Age & -0.250 & 0.250 & 0.062 & 0.056 & 9.71 & 0.062 & 9.841 & $1 / 148$ & 0.002 \\
\hline Level of education & -0.237 & 0.324 & 0.105 & 0.093 & 9.52 & 0.043 & 7.017 & $1 / 147$ & 0.009 \\
\hline \multicolumn{10}{|l|}{ Inferiority } \\
\hline Age & 0.241 & 0.241 & 0.058 & 0.052 & 9.73 & 0.058 & 9.130 & $1 / 148$ & 0.003 \\
\hline Level of education & 0.296 & 0.296 & 0.088 & 0.075 & 9.61 & 0.030 & 4.794 & $1 / 147$ & 0.030 \\
\hline Social Adjustment & \multicolumn{9}{|c|}{ No variable was included to the equation } \\
\hline \multicolumn{10}{|l|}{ Rumination } \\
\hline Age & -0.201 & 0.201 & 0.040 & 0.034 & 9.79 & 0.040 & 6.201 & $1 / 148$ & 0.014 \\
\hline Level of education & -0.177 & 0.271 & 0.073 & 0.061 & 9.65 & 0.033 & 5.246 & 147 & 0.023 \\
\hline \multicolumn{10}{|l|}{ Reflection } \\
\hline Length of incarceration & 0.188 & 0.188 & 0.035 & 0.029 & 9.82 & 0.035 & 5.445 & $1 / 148$ & 0.021 \\
\hline \multicolumn{10}{|l|}{ Self-Concept Clarity } \\
\hline Length of incarceration & 0.232 & 0.232 & 0.054 & 0.047 & 9.76 & 0.054 & 8.382 & $1 / 148$ & 0.004 \\
\hline
\end{tabular}

Note: Dependent Variables: Feminine Inventory of the Self-Concept's Gender Schemas (Inventário Feminino dos Esquemas de Gênero do Autoconceito), boldness, egocentrism, negligence, sensuality, inferiority, social adjustment; Situational Self-Awareness, rumination, reflection; Self-Concept Clarity.

Table 3

Pearson's correlation coefficient (r) between dependent variables and independent variables of the multiple regression analysis

\begin{tabular}{|c|c|c|c|c|c|c|c|}
\hline & & Age & Level of education & $\begin{array}{l}\text { Incarcerated } \\
\text { parents }\end{array}$ & $\begin{array}{l}\text { Number of } \\
\text { arrests }\end{array}$ & $\begin{array}{l}\text { Incarcerated } \\
\text { siblings }\end{array}$ & $\begin{array}{c}\text { Length of } \\
\text { incarceration (days) }\end{array}$ \\
\hline \multicolumn{8}{|l|}{ IFEGA } \\
\hline \multirow{2}{*}{ Boldness } & $r$ & 0.045 & 0.184 & -0.021 & 0.056 & -0.089 & 0.152 \\
\hline & $p$ & 0.291 & 0.012 & 0.400 & 0.246 & 0.140 & 0.031 \\
\hline \multirow{2}{*}{ Egocentrism } & $r$ & -0.170 & 0.055 & -0.169 & -0.039 & 0.014 & 0.044 \\
\hline & $p$ & 0.019 & 0.253 & 0.019 & 0.316 & 0.434 & 0.297 \\
\hline \multirow{2}{*}{ Negligence } & $r$ & -0.077 & 0.060 & -0.045 & -0.030 & -0.064 & 0.078 \\
\hline & $p$ & 0.174 & 0.234 & 0.292 & 0.359 & 0.220 & 0.173 \\
\hline \multirow{2}{*}{ Sensuality } & $r$ & -0.250 & -0.237 & -0.176 & 0.059 & 0.016 & -0.163 \\
\hline & $p$ & 0.001 & 0.002 & 0.016 & 0.237 & 0.425 & 0.023 \\
\hline \multirow{2}{*}{ Inferiority } & $r$ & -0.241 & -0.152 & -0.177 & -0.095 & 0.158 & -0.144 \\
\hline & $p$ & 0.001 & 0.032 & 0.015 & 0.123 & 0.027 & 0.040 \\
\hline \multirow{2}{*}{ Social Adjustment } & $r$ & -0.019 & -0.151 & 0.044 & 0.086 & 0.042 & -0.095 \\
\hline & $p$ & 0.406 & 0.033 & 0.295 & 0.148 & 0.305 & 0.124 \\
\hline \multicolumn{8}{|c|}{ Situational self-awareness } \\
\hline \multirow{2}{*}{ Rumination } & $r$ & -0.017 & -0.089 & 0.004 & -0.201 & 0.177 & -0.058 \\
\hline & $p$ & 0.420 & 0.140 & 0.481 & 0.007 & 0.015 & 0.242 \\
\hline \multirow{2}{*}{ Reflection } & $r$ & 0.019 & -0.047 & -0.060 & 0.082 & 0.023 & 0.188 \\
\hline & $p$ & 0.408 & 0.283 & 0.235 & 0.159 & 0.388 & 0.010 \\
\hline \multirow{2}{*}{ Self-Concept Clarity } & $r$ & 0.232 & -0.068 & 0.220 & 0.079 & 0.033 & -0.024 \\
\hline & $p$ & 0.002 & 0.205 & 0.003 & 0.169 & 0.343 & 0.386 \\
\hline
\end{tabular}

Note: Significant correlation, $p<0.05$ marked in bold.

310 IFEGA: Feminine Inventory of the Self-Concept's Gender Schemas (Inventário Feminino dos Esquemas de Gênero do Autoconceito). 


\section{Discussion}

Among the most important results of the present study, the relationship between Age and Self-concept Clarity corroborates the findings in the literature (Bardagi \& Boff, 2010; Campbell et al., 1996), which marked the advancement of ontogenetic development associated with maturity increase, seen as greater self-concept clarity and self-knowledge, and also by the improved self-concept with age. This correlation is a strong indication of the relative instability of self-concept during adulthood, which undergoes subtle structural transformations throughout life.

This result may also justify the negative correlation between Age and Egocentrism, Inferiority, and Sensuality. Throughout life, there would be stronger sense of security, which would allow more interpersonal relationships, decreased self-focus, and lower priority over sex.

The relationship between Length of Incarceration, Boldness, Reflection, and Level of Education corroborates studies that explore strategies for cognitive adaptation to situations of extreme suffering (Frinhani \& Souza, 2004), which can be important alternative approaches to mental health stability. Oliveira Braz and Farias (2015) also reported the possibility of developing subjective strategies for dealing with and escaping the oppression imposed by the constraints of the prison life. Less subservient behavior (boldness), less impulsiveness (reflection), and higher level of education change the way people perceive themselves and the way they are perceived by others in prison.

These strategies can also represent the possibility of resistance to subjection (Guimarães, Meneghel, \& Oliveira, 2006), which is commonly imposed by prisons. Such resistance is necessary for maintaining important aspects of the self. Several negative experiences undergone by women in prison, such as dealing with conflicts on a daily basis and the little opportunities for the expression of individuality, would lead to new patterns of behavior. It can be said that incarcerated women, for example, learn to distrust everything and everyone in prison, i.e., it was not a preexisting trait. It is important to highlight that boldness and reflection are not mentioned here as factors that necessarily guarantee well-being, but rather as changes in cognitive structures.

Such changes indicate more specifically selfconcept transformation that emerges from creating new possibilities of significance of inevitable experiences. A rigid and crystallized adult's selfconcept would not allow changes in the attitudinal aspects of self-concept (boldness) and the adaptive aspects of self-awareness (reflection).

The relationship between the variables Incarcerated Siblings, Incarcerated Parents, and Number of Arrests corroborate studies that show the influences of family history of criminal behavior, indicating the possibility of familiarization with criminality as one of the facets of violence (Almeida, 2006). It is worth mentioning that such familiarization refers mainly to the family discourses, in which prison is not an unknown situation, and mainly it does not determine the descendants' future criminal involvement.

Rumination presupposes reflection, and therefore recent studies have accounted for likely interactions between these two facets, although they are structurally defined as separate processes of self-awareness (Nascimento, 2008; Nascimento \& Roazzi, 2013). The findings of the present study in terms of the relationship between Rumination, Reflection, and Inferiority are consistent with the findings of those studies. Sense of inferiority and rumination can be considered elements of the self that are continuously reinforced in certain dynamics (not so strong) of self-concept. Generally, even before incarceration, women are victims of violence and abandonment, situations they experience again in prison combined with a strong feeling of loneliness (Carvalho, Valente, Assis, \& Vasconcelos, 2006; Fonseca, 2006). In such cases, the already fragile dynamics of self-concept are weakened by the new experiences of prison life.

On the other hand, reflection refers to more neutral behavior and less self-depreciation 
(Nascimento, 2008), and in the present study it was found to be strongly linked to the variables Social Adjustment, Boldness, and Sensuality. Such factors correspond to more positive attitudes of incarcerated women in relation to the dimensions of the: personal self, such as feelings; adaptive self, such as life management (boldness); and material self, such as taking care of appearance and attractiveness (sensuality). Again, our findings indicate cognitive adaptation under extreme circumstances, which is also present in the relationship found between Self-Concept Clarity and Social Adjustment.

The literature reports an association between low self-concept clarity and negative aspects of the self, such as difficulty in decision making (Setterlund \& Niedenthal, 1993). Our findings of a negative correlation between self-concept clarity, Negligence, Egocentrism, and Inferiority corroborate such findings. In other words, the higher the self-concept clarity, the greater the care for self (decreased negligence and inferiority) and for others (decreased egocentrism).

It is interesting to observe the results of the multiple linear regression analysis, such as the variation in the factors Reflection and Self-Concept Clarity due to the independent variable Length of Incarceration. This result suggests transformation in self-concept elements due to age and experiences (Caur \& Riar, 2013; Dasgupta, 2013; Hammer et al., 2014; Knutzen \& Kennedy, 2012), confirming the hypothesis examined in the present study. Again, this type of finding, in the context of Brazilian incarceration system, which still lacks effective resocialization actions, refers to changes in the use of cognitive resources as an adaptive approach. We cannot say that such changes imply benefits, at least in the current national prison model.

With regard to adaptation, the variable Length of Incarceration, which indicates the experiences undergone in prison, explains the variations in the factors that require self-awareness. Therefore, it can be assumed that there is an impact of prison on the increase in self-focus, or, conversely, that there were low levels of self-awareness prior

312 to incarceration. This latter finding is more indicative of the role of life-situational variables in changing adults' self-concept. Changes, adaptive restructuring, and new stabilization in prison are cognitive transformations that can help planning and preparing for life after prison.

The aforementioned elements show that prison is an undesirable life event in adulthood that triggers transformations in the dynamics of the self-concept of incarcerated women. This factor may be reinforced by the fact that prison is a highly unstable environment since environmental stability (provision of a certain security in terms of personal and professional life, social role, and status) plays an essential role in improving adult's self-concept. Incarceration would negatively impact the so called self-security, focusing on the malleable properties of self-concept.

Since a longitudinal investigation of the population studied was not carried out, there is need for further research. Future studies should investigate the self-concept of women who have been sentenced to longer prison terms (average of five years) soon after they arrived in prison for the first time and after years of incarceration, considering the fact that this methodological approach may reduce the size of the sample.

However, it is expected that the present study will contribute to the inclusion of lifesituational variables (which are traditionally neglected although part of the Brazilian daily life) in studies of cognitive psychology.

\section{Contributors}

L.R.M. BASÍLIO carried out the field research, conducted the literature review, and contributed to all stages of conception and design of this study, under supervision. A. ROAZZI contributed to the revising of the manuscript, development of theoretical framework, and statistical analyses. A.M. NASCIMENTO do contributed to the revising of the manuscript and to the development of the theoretical framework. J.A.C. ESCOBAR contributed to all quantitative analyses and to data processing and interpretation of both the first author's thesis and the present research. 


\section{References}

Almeida, V. P. (2006). Repercussões da violência na construção da identidade feminina da mulher presa: um estudo de caso. Psicologia, Ciência \& Profissão, 26(4), 604-619. Recuperado em junho 20, 2014, de http://www.scielo.br/pdf/pcp/v26n4/v26n4a08.pdf

Bardagi, M. P., \& Boff, R. M. (2010). Autoconceito, autoeficácia profissional e comportamento exploratório em universitários concluintes. Avaliação: Revista da Avaliação da Educação Superior, 15(1), 41-56. Recuperado em maio 10, 2014, de http://www.scielo.br/ pdf/aval/v15n1/v15n1a03

Campbell, J. D., Trapnell, P. D., Heine, S. J., Katz, I. M., Lavallee, L. F., \& Lehman, D. R. (1996). Self-concept clarity: Measurement, personality correlates, and cultural boundaries. Journal of Personality and Social Psychology, 70(1), 141-156. https://doi.org/10.1037/0 022-3514.70.1.141

Carvalho, M. L., Valente, J. G., Assis, S. G., \& Vasconcelos, A. G. G. (2006). Perfil dos internos no sistema prisional do Rio de Janeiro: especificidades de gênero no processo de exclusão social. Ciência \& Saúde Coletiva, 11(2), 461-471. https://doi.org/10.1590/S1413-812 32006000200023

Caur, A., \& Riar, T. S. (2013). Developmental changes in self-concept and emotional stability among rural adolescents of Punjab. Journal of Community Mobilization and Sustainable Development, 8(2), 282-284.

Cole, D. A., Maxwell, S. E., Martin, J. M., Peeke, L. G., Seroczynski, A. D., Tram, J. M., ... Maschman, T. (2001). The development of multiple domains of child and adolescent self-concept: A cohort sequential longitudinal design. Child Development, 72(6), 1723-1746.

Dancey, C. P., \& Reidy, J. (2006). Estatística sem matemática para psicologia ( $3^{\mathrm{a}} \mathrm{ed}$.). Porto Alegre: Artmed.

Dasgupta, N. (2013). Implicit attitudes and beliefs adapt to situations: A decade of research on the malleability of implicit prejudice, stereotypes, and the self-concept. Advances in Experimental Social Psychology, 47, 233-279.

Demo, D. H. (1992). The self-concept over time: Research issues and directions. Annual Review of Sociology, 18, 303-326. https://doi.org/10.1146/annurev.so.18.0 80192.001511

Fonseca, K. P. (2006). Re(pensando) o crime como uma relação de antagonismo entre seus autores e a sociedade. Psicologia: Ciência e Profissão, 26(4), 532-547. https://doi.org/10.1590/S1414-989320060004 00002

Frinhani, F. M. D., \& Souza, L. (2004) Mulheres encarceradas e espaço prisional: uma análise de representações sociais. Psicologia: Teoria e Prática, 7(1), 61-79.
Recuperado em maio 5, 2015 de http://www.redalyc. org/html/1938/193817415006/

George, L. (2000). Well-being and sense of self: What we know and what we need to know. In K. W. Shaide \& J. Hendricks (Eds.), The evolution of the aging self: The societal impact on the aging process (pp.1-35). New York: Springer. (Societal Impact on Aging Series).

Giavoni, A., \& Tamayo, A. (2000). Inventário dos Esquemas de Gênero do Autoconceito (IEGA). Psicologia: Teoria e Pesquisa, 16(2), 175-184. https://doi.org/ 10.1590/S0102-37722000000200010

Giavoni, A., \& Tamayo, A. (2005). Inventário Feminino dos Esquemas de Gênero do Autoconceito (IFEGA). Estudos de Psicologia (Natal), 10(1), 25-34. https:// doi.org/10.1590/S1413-294X2005000100004

Guimarães, C. F., Meneghel, S. N., \& Oliveira, C. S. (2006). Subjetividade e estratégias de resistência na prisão. Psicologia: Ciência e Profissão, 26(4), 632-645. https:// doi.org/10.1590/S1414-98932006000400010

Hair Junior, J. F., Anderson, R. E., Tatham, R. L., \& Black, W. C. (2005). Análise multivariada de dados (5a ed.). Porto Alegre: Bookman.

Hammer, M., Hammer, B., \& Butler, A. (2014). Psychological healing through creative selfunderstanding and self-transformation. Houston: Strategic Book Publishing.

Knutzen, K. B., \& Kennedy, D. M. (2012). Designing the self: The transformation of the relational self-concept through social encounters in a virtual immersive environment. Interactive Learning Environments, 20(3), 271-292. https://doi.org/10.1080/1049482 0.2011 .641680

L'Écuyer, R. (1978). Le concept de soi. Paris: PUF.

L'Écuyer, R. (1985). El concepto de sí mismo. Barcelona: Oikos-Tau.

Mortimer, J. T., Finch, M. D., \& Kumka, D. (1981). Persistence and change in development: The multidimensional self-concept. In P. B. Baltes \& O. G. J. Brim (Eds.), Life-span development and behavior (Vol.4). New York: Academic Press.

Nascimento, A. M. (2008). Autoconsciência situacional, imagens mentais, religiosidade e estados incomuns da consciência: um estudo sociocognitivo (Tese de doutorado não-publicada). Universidade Federal de Pernambuco, Recife.

Nascimento, A. M., \& Roazzi, A. (2013). Autoconsciência, imagens mentais e mediação cognitiva. Psicologia: Reflexão e Crítica, 26(3), 493-505. https://doi.org/10. 1590/S0102-79722013000300009

Oliveira Braz, J. M., \& Farias, F. R. (2015). Memória e poder disciplinar: transformação e produção subjetiva em escolas prisionais. InterSciencePlace, 10(3), 67-83. 
Reis, E. (2001). Estatística multivariada aplicada ( $2^{\mathrm{a}}$ ed.). Lisboa: Edições Silabo.

Rocha, A. P. (2007). O autoconceito nos idosos (Dissertação de mestrado não-publicada). Universidade de Lisboa, Portugal.

Setterlund, M. B., \& Niedenthal, P. M. (1993). "Who am I? Why am I here?" Self-esteem, self-clarity, and prototype matching. Journal of Personality and Social Psychology, 65(4), 769-780. https://doi.org/10.1037/ 0022-3514.65.4.769
Tamayo, A. (1981). EFA: Escala Fatorial de Autoconceito. Arquivos Brasileiros de Psicologia, 33(4), 87-102. Recuperado em junho 16, 2013, de http://www. scielosp.org/scieloOrg/php/reflinks.php?refpid=S $1413-8123200300030000200036 \&$ lng=en\&pid= \$1413-81232003000300002

Received: June 9, 2015

Final version: April 14, 2016

Approved: June 1, 2016 